\title{
Cultural Heritage Tourism in Malaysia: Issues and Challenges
}

\author{
Norhasimah Ismail ${ }^{1}$, Tarmiji Masron ${ }^{2}$, Azizul Ahmad ${ }^{3}$ \\ 1,2,3 Department of Geography, School of Humanities, Universiti Sains Malaysia, 11800, Penang, \\ Malaysia
}

\begin{abstract}
Malaysia is experiencing an incredible pace of tourism development and heritage tourism is one of the tourism branches that have long contributed to appeal the tourist destination and acts as important marketing tool to attract tourist especially with special interests in heritage and arts. Cultural heritage tourism has emerged as a potential form of alternative tourism among both international tourists as well as Malaysian domestic travelers. The difference of ethnics present in Malaysia brought different local knowledge discipline ranging from its architecture, handicrafts, traditional attire, music and dance, which reflects a colorful heritage and an amalgamated culture. There are arise of conflict in management of cultural heritage tourism in Malaysia face by tourism managers, stakeholders, governments, cultural heritage managers and local community itself. In order to maintain, conserve and preserve the resources and assets of cultural heritage in Malaysia, a system or management need to be develop that take into consideration on every issues and challenge, so that the decision making process is reliable to optimize the value of cultural heritage tourism industry in Malaysia. The purpose of this paper is to give an overview and discuss the status, issues and challenge of cultural heritage tourism in Malaysia.
\end{abstract}

\section{Introduction}

Tourism is the set of activities engaged in by persons temporarily away from their usual environment, for a period of not more than one year, and for a broad range of leisure, business, religious, health, and personal reasons, excluding the pursuit of remuneration from within the place visited or long-term change of residence [1]. Tourism has bloomed as a major economic element of the world market and has become one of the largest industries in the world, since World War II [2]. There are different categories and varieties of tourism occurs recognized by EU-Committee of the Regions (2006), such as coastal tourism, urban tourism, island tourism, rural tourism and mountain tourism [3].

Within the tourism sector, coastal tourism is by far the most significant in terms of tourist flows and generation of income, but nowadays the new trends tourism emerged known as cultural heritage tourism. This trend is evident in the rise in the volume of tourists who seek adventure, culture, history, archaeology and interaction with local people [4]. Cultural heritage tourism is defined as travelling to experience the places and activities that authentically represent the stories and people of the past and present $[4,5]$. 
Cultural heritage tourism has long existed, but recent demographic, social, and cultural changes in the main source countries have led to an increasing number of new niche markets in destination countries, including culture-oriented holidays. Cultural heritage tourism is important for various reasons; it has a positive economic and social impact, it establishes and reinforces identity, it helps preserve the cultural heritage, with culture as an instrument, it facilitates harmony and understanding among people, it supports culture and helps renew tourism [6].

Culture and cultural heritage are crucial to people's identity, self-respect, and dignity, which apply to both affluent and poor societies. The World Tourism Organization (WTO) predicts that cultural tourism will be one of the five key tourism market segments in the future, and notes that growth in this area will present an increasing challenge in terms of managing visitor flows to cultural sites [7]. Cultural heritage tourism can encourage the revival of traditions and the restoration of sites and monuments. However, unbridled tourism can have the opposite effect.

Cultural heritage tourism viewed as travel anxious with experiencing cultural environments, including landscapes, the visual and performing arts, and special lifestyles, values, traditions and events. It is vital to stress that cultural heritage tourism involves not only tangible or visible heritage such as sites, colors, materials, and settlement patterns, but also intangible heritage such as societal structures, traditions, values, and religion. The aim of this paper is to discuss the status, issues and challenge of cultural heritage tourism in Malaysia.

\section{Cultural Heritage Tourism in Malaysia}

The cultural heritage matters to individuals, ethnic groups, nations, and the international community. The values of cultural heritage are various: symbolic, historic, informational, aesthetic and economic (Table 1) [8]. There are two forms of cultural heritage present in Malaysia, known as tangible and intangible. Tangible cultural heritage can be found in the form of buildings or artifacts, while intangible cultural heritage was in terms of people's values, attitudes and way of life, that may have existed or exist in relation to the heritage of Malaysia or any part of Malaysia or in relation to the heritage of a Malaysian community [9].

In other words, cultural heritage can be seen in many forms including buildings, areas, dance, food, dress, events, values, lifestyles and handicrafts. Given the values of cultural property, many problems created when such materials was damaged, destroyed, or removed from its context. These losses include the damage or loss of buildings of historical importance, archaeological sites, monuments, and objects; the loss of traditional knowledge and "scientific" information; the loss of access to objects of cultural or national importance; and the alienation of people from their culture or the loss of national pride.

Interpretation of cultural heritage is an integral aspect of both visitor experience and conservation of heritage. Interpretation needs to widen its debate to incorporate more experiential components as noted above. There is also a specific need to research interpretation in relation to cultural heritage tourism specifically, as distinct from broader interpretation or heritage interpretation research. Gaps in current interpretation research for cultural heritage tourism as defined for this project include:

- the role of interpretation as both a tool of education and visitor experience, and as a means of achieving cultural heritage conservation

- training and education for interpretation development, delivery and assessment

- closing the gap between manager knowledge and public experiences

- developing products to assist in the development of appropriate interpretation

- measuring success of interpretation of cultural heritage

- interpretation and promotion of novel or niche aspects of cultural heritage, for example agricultural and industrial heritage

- broadening tourist experiences through multiple modes of interpretation

- Contestation and authenticity in heritage tourism. 
Cultural heritage tourism is traveling to experience the places and activities that authentically represent the stories and people of the past and present, which include historic, cultural and natural attractions. Cultural Heritage is an appearance of the ways of living developed by a community and passed on from generation to generation, including customs, practices, places, objects and artistic expressions. Other than that, cultural heritage also expressed as either intangible or tangible cultural heritage. Cultural Heritage can be distinguished into three types; built environment (buildings, townscapes, archaeological remains); natural environment (rural landscapes, coasts and shorelines, agricultural heritage); and artifacts (books \& documents, objects, pictures) (Figure 1).

Cultural heritage tourism has a number of objectives that must be met within the context of sustainable development such as; the conservation of cultural resources, accurate interpretation of resources, authentic visitors experience, and the stimulation of the earned revenues of cultural resources. Therefore, cultural heritage tourism is not only concerned with identification, management and protection of the heritage values but it must also be involved in understanding the impact of tourism on communities and regions, achieving economic and social benefits, providing financial resources for protection, as well as marketing and promotion. [11,12].

Table 1. Cultural Heritage Values [8]

\begin{tabular}{|c|c|c|}
\hline No. & Values & Details \\
\hline 1 & Symbolic & $\begin{array}{l}\text { Cultural property provides awareness of and pride in cultural identity. In the } \\
\text { postcolonial world, the idea of a national cultural heritage is of particular } \\
\text { importance to emerging nations, and the protection of cultural property is a } \\
\text { highly political issue }\end{array}$ \\
\hline 2 & Historic & $\begin{array}{l}\text { The cultural heritage represents eras and sometimes civilizations that have } \\
\text { passed. Much of this heritage symbolizes a florescence of a region's traditions } \\
\text { and cultures. Heritage is often of particular importance to non-literate societies } \\
\text { and to segments of literate societies often ignored in conventional "historical" } \\
\text { documents. In countries such as Australia, we see the implications of cultural } \\
\text { heritage in connecting Aboriginal communities with their past and with the } \\
\text { continuation of traditional lifestyle }\end{array}$ \\
\hline 3 & Informational & $\begin{array}{l}\text { The cultural heritage is essential to both public education and scholarly research. } \\
\text { Archaeologists, historians, and ethnographers use material culture to study } \\
\text { ancient and traditional cultures. Information about how other cultures met } \\
\text { challenges to their existence can help us as we meet the demands of our own } \\
\text { world. The study of other cultures can also lead to new intellectual } \\
\text { achievements. For scholars, the greatest informational value comes in studying } \\
\text { cultural property within its original context. }\end{array}$ \\
\hline 4 & Aesthetic & $\begin{array}{l}\text { The cultural heritage can provide an aesthetic, emotional experience for the } \\
\text { viewer, leading to personal growth and development. Moreover, these buildings, } \\
\text { artworks, and artifacts can serve as a creative inspiration for contemporary } \\
\text { artists, both those working within traditional forms and those working in a } \\
\text { modern style. }\end{array}$ \\
\hline 5 & Economic & $\begin{array}{l}\text { Cultural property - comprising archaeological sites, monuments, historic } \\
\text { buildings and quarters, and archaeological and ethnographic materials in } \\
\text { museums-is an important focus of tourism in many nations. As such, this } \\
\text { tourism, which can be local, national, or international, generates employment } \\
\text { and revenue. }\end{array}$ \\
\hline
\end{tabular}


Malaysia has a long tradition of tourism, attracting travelers fascinated by the art, architecture, handicrafts, traditional attire, music and dance, which reflects a colorful heritage and an amalgamated culture. Malaysia consists of Malays, Chinese, Indian, and other indigenous groups including the Orang Asli, Dayaks, Kadazan Dusun, Melanau, Murut and more. Joining them are groups of mixed descent, such as the Baba-Nyonyas and Eurasians of Portuguese and other European ancestry, as well as other immigrant Asian ethnicities.

Although each of these cultures has retained their religions, customs and way of life, they have also blended together to create Malaysia's diverse heritage. Malaysia's heritage is a unique expression of our history and our national identity. It enriches Malaysian lives, and provides a meaningful foundation on which to base the future national development. Yet in many places, precious cultural heritage is under threat from new developments, mostly due to lack of awareness of its historical and architectural significance.

Coupled with the growth in tourism, cultural heritage tourism has emerged as a potential alternative tourism among both international tourists and Malaysian domestic travelers. Cultural heritage tourism in Malaysia attracted great publicities with the increase in the number of incoming tourists annually, due to its marvelous cultural heritage resources that are readily available to be explored such as the existence of multi-cultural, historical buildings, colorful lifestyles and friendly atmosphere.

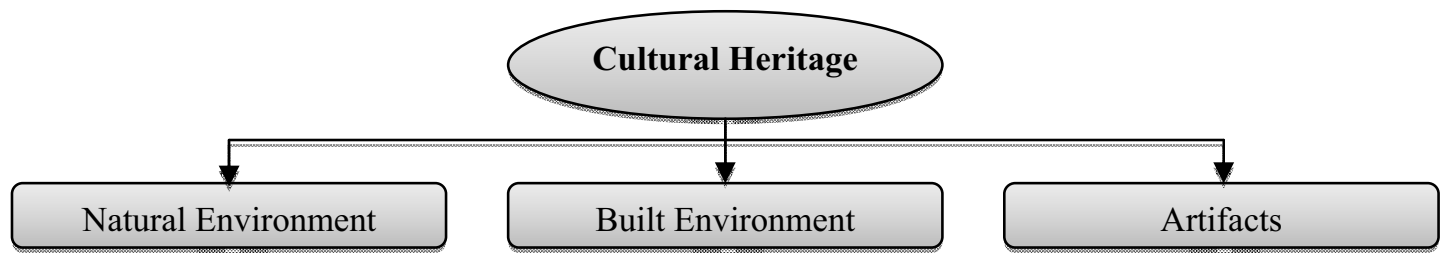

Figure 1. Different Types of Cultural Heritage [10]

\section{Issues and Challenge}

Tourism is a powerful economic development tool, which creates jobs, provides new business opportunities and strengthens local economies. It helps to protect our nation's natural and cultural treasures and improve the quality of life for residents and visitors alike if cultural heritage tourism development using a proper planning. In the former year, the primary role of tourism industry was acting as marketing ready products to tourists. Nowadays, tourism, preservation, heritage and culture are much more likely to overlap, where some state tourism offices now help develop heritage resources, and a number of preservation organizations are marketing their sites to tourist. The promotion of cultural heritage tourism in Malaysia faces numerous underlying issues that both related to the complexity of the society living in Malaysia.

The tourism industry is driven mainly by private agencies with the prime motivation of generating profit. The are several issues that need to be review to develop a success cultural heritage tourism industry especially in understanding different perspectives between tourism operators, cultural heritage managers and the communities itself. Tourism operator run a tourism business and serve customer but have constraints in accessing to the site they want to visit and their products. Tourism operator depends on a market that can have strong seasonal variation such as holiday periods and yearly events. Tourism operators need a great deal of certainty in access, timing and facilities to deliver reliable and efficient service to domestic and international clients.

Heritage managers have a primary duty to protect and conserve the site under their control. The cultural heritage such as arts performance, dance and events, may be not affected directly from development of tourism industry and increasing of tourist arrivals, but cultural heritage site may be 
affected. Because of the fragility of the site, public access to heritage site is not always appropriate or may have to be restricted. Other than that, heritage managers have obligations and strong ethic of providing education and recreation for public about the site in their care. Other than tourism operator and heritage managers, there is also local community where the heritage site located where they may be keen to develop tourism but they may also protective of their privacy and wary of the effects that tourism might have.

Therefore, it is important to establish early needs, interests and aspiration of the local community. Local communities should be consulted with the tourism planning, development and operation of the heritage site. With the involvement of local communities, it will help ensuring that the tourism activity is sensitive to community purposes and ambition. It also will be able to capture the essence of the site and its people. Table 2 below showed the list of issues that arise in cultural heritage tourism industry faced by tourism operators, heritage managers and local communities.

One of the issues and challenges in managing cultural heritage asset in Malaysia are in terms of funding. Managing cultural heritage assets such as heritage building, is considered as expansive and costly to some people, which normally funded by government or private institution. In Malaysia, national heritage are put under the supervision of Ministry of Information, Communications and Culture (KPKK).

For example, the demolition of Bok House since the process of conservation of the house considered expansive. The Bok House (better known as Le Coq d'Or), was situated on 121, Jalan Ampang, Kuala Lumpur, and was built in 1926 and completed in 1929, for Chua Cheng Bok, who is famed as the founder of Cycle and Carriage [13]. This demolition was decided soon after the National Heritage Act 2005 was gazette, which cause the conflict arises between Badan Warisan Malaysia and government.

Table 2. Issues Arise in Cultural Heritage Tourism Industry Faced by Tourism Operators, Heritage Managers and Local Communities

\begin{tabular}{|c|c|c|}
\hline No. & Peoples & Issues \\
\hline 1 & $\begin{array}{l}\text { Tourism } \\
\text { operators or } \\
\text { enterprise }\end{array}$ & 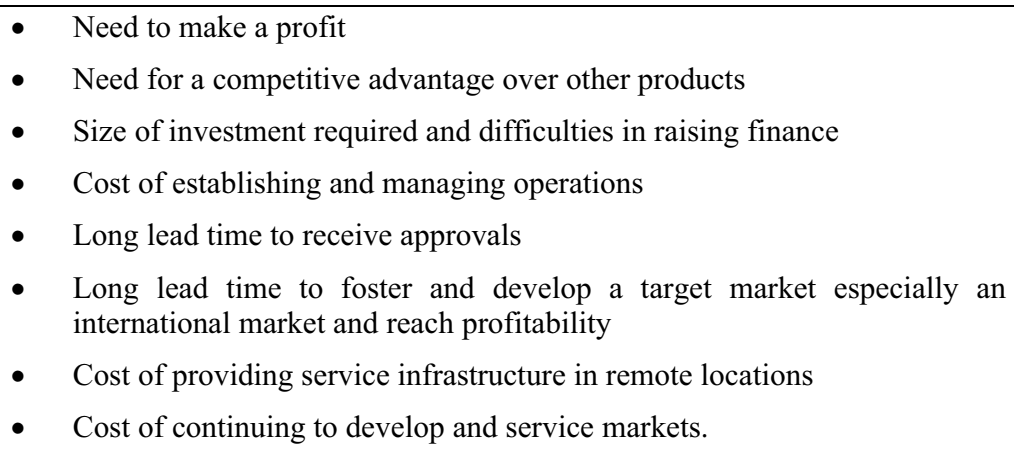 \\
\hline 2 & $\begin{array}{l}\text { Heritage } \\
\text { managers }\end{array}$ & $\begin{array}{l}\text { - Tension between the need to protect the site and the pressure to provide } \\
\text { for public access } \\
\text { - Pressure for scant resources for conservation to be diverted to managing } \\
\text { tourism } \\
\text { - Assessment of the impacts tourism might have on the site and fear for the } \\
\text { impacts that may be difficult to predict } \\
\text { - Sensitivity regarding the information about the location, direction of } \\
\text { heritage site which public access may be undesirable } \\
\text { - The effect of increasing visitor to the surrounding areas, wildlife and } \\
\text { vegetation } \\
\text { - The physical capacity of the site to handle visitor }\end{array}$ \\
\hline
\end{tabular}




\begin{tabular}{|c|c|c|}
\hline No. & Peoples & Issues \\
\hline & & $\begin{array}{l}\text { - } \quad \text { Cumulative effects of tourism growth over time } \\
\text { - The need to provide visitor facilities } \\
\text { - Fears of loss of control of interpretation and inaccuracy and manipulation } \\
\text { of messages } \\
\text { - } \quad \text { Effect and influence of volunteers and sponsors on the management of the } \\
\text { site } \\
\text { - The cultural and intellectual property implications of tourism such as } \\
\text { respect for sensitive information, copyright and use of images in } \\
\text { marketing and promotion }\end{array}$ \\
\hline 3 & $\begin{array}{l}\text { Local } \\
\text { communities }\end{array}$ & $\begin{array}{l}\text { - Whether the visitor attraction is presenting a local community perspective } \\
\text { - Whether community leaders have been identified and actively consulted } \\
\text { - Whether religious or cultural sensitivities associated with the use or } \\
\text { presentation of heritage site have been adequately taken into account } \\
\text { - How local people can take an active role in negotiating the presentation, } \\
\text { management and operation of the attraction } \\
\text { - How tourism industry give benefits for local people in maximized } \\
\text { - How negative impacts of tourism development can be reduced }\end{array}$ \\
\hline
\end{tabular}

The Badan Warisan Malaysia asked the government to rectify clear guideline of the government's definition of heritage is and what criteria applied to arrive at this decision when the nomination of Bok House as a national heritage disapproved [14]. Other issues and challenge is which typically associated with management of cultural heritage. In Malaysia, problem such as lack of conservation officers, economic recession, lack of collaboration, lack of awareness on the importance of cultural heritage asset, and others.

Involvement of stakeholders, particularly the locals is very important [15], and it is best to leave the matter of conservation techniques to them since they are traditionally associated with the area and cultural heritage asset itself. On management and stakeholder's aspect, a few issues had been identified such as directions, objectives and approach adopted by stakeholders for the management of the cultural heritage area. Some of the areas have more than one stakeholders and it might cause conflict among them, since each stakeholder work within its own scope, roles, funding and policy. Bukit Jugra, known as popular heritage sites, has valuable assets that need to be managed carefully, but there are still weaknesses to be seen, indicating that the experts have not performed their task to the optimum, poor maintenance and lack of control of the expert appointed [16].

In terms of cultural heritage resources, the issues can be divided into four aspects, which are conservation, biodiversity, geographical factor, as well as facilities and amenities. As a cultural heritage area, conservation is vital and based on observation in few areas in Malaysia, most of the cultural heritage resources especially buildings are underutilize. If the resources were managed poorly and lack of maintenance, it will caused buildings and monuments to decay.

Other than that, the presence of multicultural communities in Malaysia made it difficult for tourism planners and managers to decide which cultural heritage need to be promoted. There are issues arise where Chinese and Indians community have felt that their culture heritage are not well represented and promoted by the government. One of the key challenges in managing and promoting cultural heritage tourism in Malaysia is development of a system or management that take into consideration on every stakeholders concern.

Currently, the cultural heritage tourism in Malaysia was managed by different stakeholders in each cultural heritage area. In order to maintain, conserve and preserve the resources and assets of cultural heritage, decision making process must be reliable to optimize the value of heritage assets and to ensure its consistence with the principles and guidelines stated. Based on observation, there is also 
lack of collaborations to date in terms of managing the assets between the local authority and other stakeholders, since they are working independently without having a shared interest as a basis for their tasks. It was also proven challenging to find sufficient financial support and fund in managing heritage assets which is very important so that the management process will not unfairly burdening the stakeholders especially the community in the future.

\section{Conclusion}

Preserving the world's cultural heritage for the enrichment and education of present and future generations is crucial. A great deal of tourism relies on places with natural, indigenous and historic significance which tourism products are based. In order to respect the cultural significance of the destination, people involve in tourism industry need to be sensitive to cultural groups who have a special interest in them and they need to directly involve in the planning and promotion of the destination. Cultural Heritage resources will play a significant role in sustainable cultural, social, economic development of communities, so the physical fabric, that has influenced their creation, has also to be maintained. Therefore, the careful planning of cultural-heritage tourism leads to sustainable regional development. It is crucial to find a proper way to settle the issues and challenges arise during managing and promotion of cultural heritage tourism, and once is taken into action it will lead to the heritage tourism development model that will lead to the bright prospects of the overall tourism business in the region.

\section{Acknowledgement}

This paper is part of the Research University Grant for Cluster (RUC) 1001/PTS/8660014. Tourism Decision Support System, Sustainable Tourism Research Cluster USM, Malaysia.

\section{References}

1. S. Smith, The measurement of global tourism: Old debates, new consensus, and continuing Challenges. In A. A. Lew, C.M. Hall, \& A.M. Williams, A companion to tourism. Oxford: Blackwell 25-35 (2004)

2. E. Chambers, Introduction: Tourism Mediators. In E. Chambers, Tourism and Culture: An Applied Perspective. Albany: State University of New York Press 1-12 (1997)

3. E.U. Committee of the Regions, Sustainable Tourism as a Factor of Cohesion among European Regions. Belgium: European Communities (2006)

4. B. Chourasia, A. Chourasia, Prospects of Heritage Tourism Management in Bokaro of Jharkhand. VSRD Int. J. of Bus. and Manage. Research, 2 ,10 (2012)

5. National Trust for Historic Preservation, Heritage Tourism (2014). Accessed from http://www.preservationnation.org/information-center/economics-of-revitalization/heritagetourism/\#.VAOTNvmSwi5 (29 August 2014)

6. G. Richards, Production and consumption of European Cultural Tourism. Annals of Tourism Research Tillburg University Press. (2006)

7. World Tourism Organization (WTO), Tourism 2000: Building a Sustainable Future for AsiaPacific. Final Report, Asia Pacific Ministers' Conference on Tourism and Environment. WTO: Madrid (1997)

8. C.L. Costin, Legal and Policy Issues in the Protection of Cultural Heritage in South Asia and the Pacific. In Margaret G.H. Mac Lean (Editor), Cultural Heritage in Asia and the Pacific: Conservation and Policy. Proceedings of a symposium held in Honolulu, Hawaii, USA, 8-13 September 1991 (1993)

9. M.H. Safinaz, M.N. Mahmud Zuhdi, A.M. Nazura, Bringing Life to Folklore: Problem of Definition. Jurnal Undang-undang \& Masyarakat, 15 (2001) 
10. Culture in Development (CID), What is Cultural Heritage. Accessed from http://www.cultureindevelopment.nl/Cultural_Heritage/What_is_Cultural_Heritage (8 August 2014).

11. P.V. Joshi, Planning Cultural-Heritage Tourism for Sustainable Development. Golden Research Thoughts, 1 XI (2012). ISSN No-2231-5063. (2014)

12. The Island, Heritage \& Heritage Tourism in Sri Lanka (2011). Accessed from: http://www.island.lk/index.php?page_cat $=$ article-details\&page $=$ article-details\&code_title $=35614$ (27 September 2011)

13. Badan Warisan Malaysia, Cultural Significance Statement: Badan Warisan Malaysia appeals for Bok House to be gazette as National Heritage under the National Heritage Act 2005 (2006). Accessed from: http://www.badanwarisan.org.my/images/uploads/bokcss170706.doc. (28 August 2014)

14. The Star Online, Bok House on Jln Ampang demolished (2006). Accessed from: http://www.thestar.com.my/story/?file=\%2f2006\%2f12\%2f15\%2fnation\%2f20061215210439\&s ec=nation (29 August 2014)

15. P. Howard, P. Heritage: Management, interpretation, identity. New York, Continuum International Publishing Group (2003).

16. B. Aidatul Fadzlin, A.Y. Nooridayu, J. Norajlin, Managing Heritage Assets: Issues, challenges and the future of historic Bukit Jugra, Selangor. Procedia-Social and Behavioral Sciences, 68, 341 - 352 (2012) 